\title{
ПРОБЛЕМНЫЕ АСПЕКТЫ РЕАЛИЗАЦИИ ПРАВА НА ОБЯЗАТЕЛЬНУЮ ДОЛЮ В НАСЛЕДСТВЕ
}

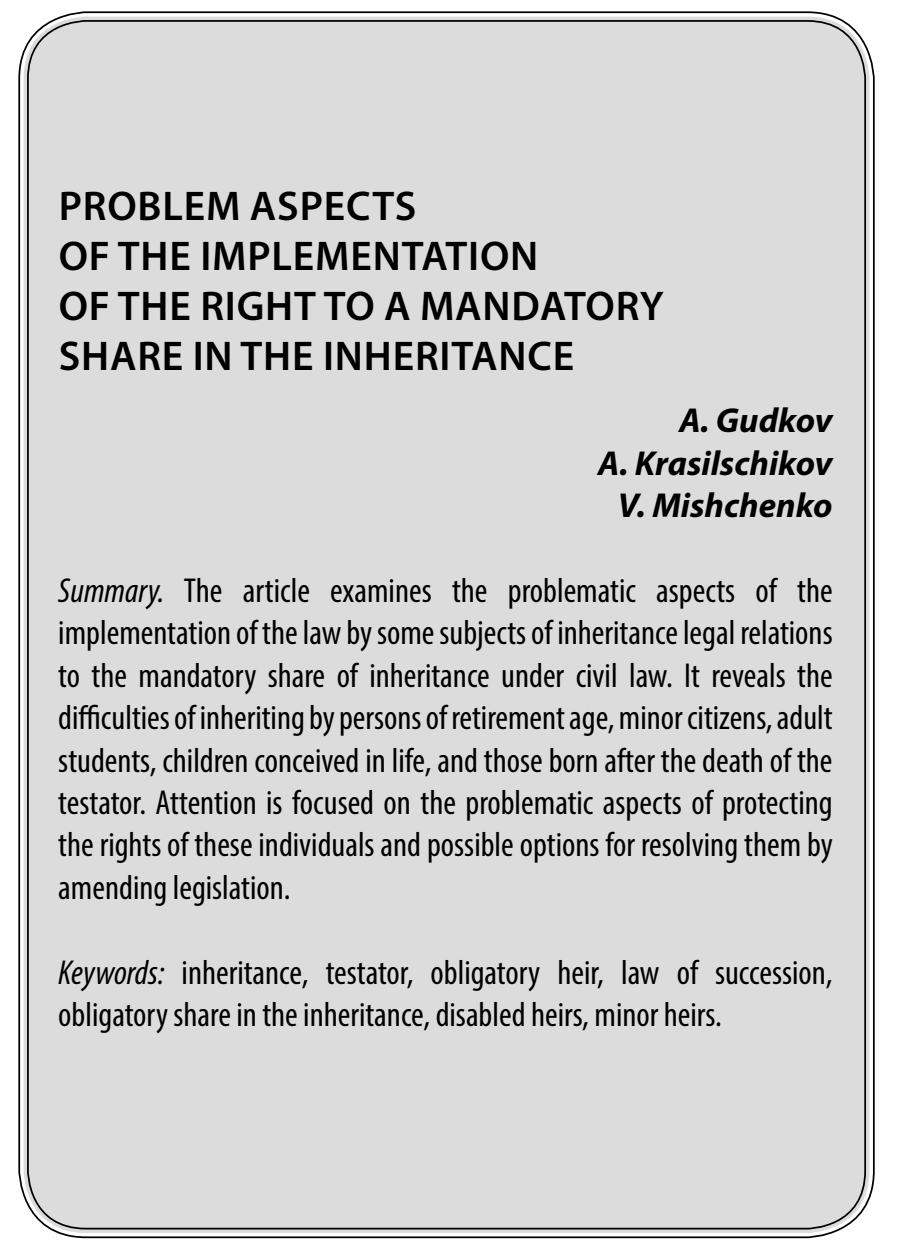

$\Pi$ ринятие наследства представляет собой соблюдение определенного порядка очередности и прав лиц, имеющих обязательную долю в наследстве независимо от воли наследодателя. Наследственное право устанавливает возможность сохранения наследства после смерти наследодателя за определенными лицами, которые кроме родственных взаимоотношений имеют признаки материальной зависимости от наследодателя. В частности, согласно статье 1149 Гражданского Кодекса РФ [1] обязательною долю в наследстве имеют его дети, иждивенцы, родители или супруг, при этом указанные наследники должны иметь соответствующие признаки: быть несовершеннолетними или нетрудоспособными в силу возраста или здоровья. Также нотариус должен не только установить нетрудоспособность наследника обязательной доли, но и обстоятельство его материальной зависимости от наследодателя. Так, Определением Судебной коллегии по гражданским де-
Гудков Анатолий Иванович К.ю.н., дочент, Владимирский юридический институm ФСИН России gudkovaniv@yandex.ru

Красильщиков Анатолий Владимирович К.ю.н., дочент, Владимирский юридический инстиmym ФСИН России krasilschikov@inbox.ru Мищенко Вячеслав Иванович К.ф.н., дочент, Владимирский юридический институm ФСИН России vyacheslav-mischenko@mail.ru

Аннотация. В статье исследованы проблемные аспекты реализации права некоторыми субъектами наследственных правоотношений на обязательную долю наследства по гражданскому законодательству. Раскрываются трудности вступления в наследство лицами пенсионного возраста, несовершеннолетними гражданами, совершеннолетними учащимися лицами, детьми, зачатыми при жизни, а родившимися после смерти наследодателя. Акцентируется внимание на проблемных аспектах защиты прав указанных лиц и возможные варианты их разрешения путем внесения изменений в законодательство.

Ключевые слова: наследство, наследодатель, обязательный наследник, наследственное право, обязательная доля в наследстве, нетрудоспособные наследники, несовершеннолетние наследники.

лам Верховного Суда РФ от 12.07.2016 N49-КГ16-10 дело было возвращено на новое рассмотрение в связи с тем, что суд первой инстанции не выяснил вопрос нахождения нетрудоспособного наследника обязательной доли на иждивении наследодателя не меньше одного года независимо от места его проживания.

При этом нетрудоспособными считаются такие граждане, которые в силу нетрудоспособного возраста или болезни не могут быть трудоспособными и, соответственно, не работают. В частности, лица, достигшие пенсионного возраста, считаются нетрудоспособными наравне с несовершеннолетними гражданами. Согласно Закону «О государственном пенсионном обеспечении в РФ» [3] пенсионерами по возрасту считаются мужчины, достигшие 65 лет, а женщины - 60 лет, за исключением лиц, проживающих в условиях Крайнего Севера, которым снижен данный возрастной порог. При этом по закону 
условием нетрудоспособности пенсионеров считается отсутствие трудовой деятельности в период получения пенсионного обеспечения. Таким образом, на момент смерти наследодателя работающий супруг-пенсионер по данному закону не будет является лицом, имеющим право на обязательную долю в наследстве, так как не являлся иждивенцем. Данное обстоятельство вызывает немало споров в юридической практике, потому что возникает вопрос о размере заработка пенсионера.

С одной стороны, концепция нетрудоспособности заключается в невозможности лица осуществлять трудовую деятельность. Однако, с учетом современных способов зарабатывания денег, стоит возразить данному утверждению. В частности, инвалиды I, II и III групп, несмотря на имеющуюся у них инвалидность, имеют право на работу по силам (умственный труд), хотя не считаются трудоспособными гражданами и не лишаются пенсии, если имеют дополнительный заработок. Следовательно, данная норма существенно ограничивает права пенсионеров, имеющих дополнительный заработок, на получение обязательной доли в наследстве.

Нетрудоспособные лица в силу возраста имеют свои отличительные обстоятельства, которые вызывают спорные суждения. Во-первых, общим признаком совершеннолетия является наступление восемнадцатилетнего возраста. Но в то же время, пятнадцатилетний гражданин, а в некоторых случаях и 14-летний, согласно Трудовому Кодексу РФ [2] имеет право на трудоустройство. В то же время шестнадцатилетний гражданин может быть индивидуальным предпринимателем, а, следовательно, приобрести трудоспособность, будучи несовершеннолетним. Поэтому нотариусы при оформлении наследства для установления обязательной доли несовершеннолетнему лицу в возрасте от 16 до 18 лет вполне обоснованно могут затребовать документы, доказывающие отсутствие трудовой деятельности несовершеннолетнего.

В то же время наследники в возрасте до 23 лет, обучающиеся в учебных заведениях на очной форме обучения в образовательных заведениях среднего и высшего образования, также будут считаться иждивенцами, имеющими право на обязательную долю в наследстве, несмотря на совершеннолетний возраст.

Таким образом, по субъектному составу наследником обязательной доли может быть исключительно физическое лицо, имеющее совокупные ограничения по возрасту, трудоспособности или по здоровью. При этом стоит отметить, что зачатый, но не рожденный наследник на момент смерти наследодателя, тоже является претендентом на обязательную долю в наследстве, но, однако, она может быть принята родителем ребенка не ранее, чем после его рождения и получения свидетельства о рождении [4].

Так как работающие несовершеннолетние не могут считаться нетрудоспособными, то данное обстоятельство может быть препятствием в получении обязательной доли. По нашему мнению, данное обстоятельство требует корректировки формулировок в законе: в частности, в статье 1149 ГК РФ [1] необходимо установить возраст несовершеннолетних лиц и указать условия их вступления в наследство независимо от трудовой занятости.

Обязательная доля в наследстве - законная часть имущества наследодателя, которая передается наследнику вне зависимости от наличия завещания или волеизъявления других наследников. Как правило, размер обязательной доли рассчитывается из общей стоимости наследственной массы с учетом количества наследников. В частности, В качестве обязательной доли закон определяет не меньше половины стоимости доли, которая причиталась бы каждому наследнику по закону.

Объектом наследования могут выступать делимые и неделимые вещи, права и предметы домашнего обихода. В частности, закон устанавливает право иждивенца, имеющего обязательную долю в наследстве и проживавшего вместе с наследодателем, получить в счет своей доли преимущественно перед другими наследниками предметы домашней обстановки и обихода.

При этом наследник обязательной доли в случае невозможности получения конкретного наследственного имущества в случае его неделимости может получить компенсацию его действительной стоимости от других наследников.

Условиями получения обязательной доли являются:

1. Проживание нетрудоспособного наследника вместе с наследодателем на одной территории в течение года до его смерти;

2. Нахождение наследника на иждивении.

Закон различает также способы выделения доли в зависимости от положения наследников: при наличии завещания стоимость обязательной доли удовлетворяется из части имущества, не входящей в завещание, даже в ущерб остальным законным наследникам. А в случае недостаточности имущества обязательная доля в непогашенной части удовлетворяется из наследства по завещанию. Таким образом, законодатель выделяет обязанность выплаты обязательной доли, независимо от количества наследников, очередности и стоимости наследственной массы. 
При этом размер обязательной доли не является фиксированным, хотя и имеет граничный порог и зависит от ряда обстоятельств. В частности, ГК РФ определяет возможность уменьшения обязательной доли наследника либо отказ от обязательной доли в пользу иных наследников.

Так, Определением Верховного Суда РФ от 05.11.2019 года по делу № 5-КГ19-181 [5] отменил решения суда первой и апелляционной инстанции, направив дело на повторное рассмотрение, в связи с тем, что судами не были учтены обстоятельства, указанные в части 4 статьи 1149 ГК РФ [1], свидетельствующие об уменьшении обязательной доли наследника (дочери наследодателя), которая не проживала в доме умершего отца в отличие от законной наследницы - его жены, которая требовала уменьшения обязательной доли.

Кроме того, нотариус, принимающий решение о наследстве, вправе отказать наследнику в выдаче обязательной доли, если возникли обстоятельства, при которых будет установлено, что наследник по завещанию пользовался имуществом наследодателя или использовал данное имущество в качестве основного источника существования (проживал в жилом доме, пользовался дачей), а держатель обязательной доли, напротив, не пользовался данным имуществом. Таким образом, возникает законодательное противоречие, при котором обязательная доля теряет свойство обязательности и нивелируется.

Уменьшение обязательной доли взаимосвязано также с двумя обстоятельствами:

1. Имущественное положение наследников;

2. Стоимость наследственного имущества, полагающегося на обязательную долю, значительно превышает размер средств, необходимых на содержание нетрудоспособного или несовершеннолетнего гражданина.

В свою очередь, размер содержания определяется путем оценки совокупных обстоятельств, исходя из разумных потребностей гражданина и размера его финансовых обязательств перед третьими лицами, его уровня жизни на момент смерти наследодателя.

Таким образом, «плавающая» стоимость обязательной доли требует определенных средств доказывания со стороны заинтересованного наследника обязательной доли.

Утрата наследником обязательной доли также зависит от двух обстоятельств:

1. Утрата наследником обязательной доли в силу закона (отказ нотариуса);
2. Наследник является выгодоприобретателем наследственного фонда, от которого он не отказался.

При этом согласно статье 1158 ГК РФ [1] добровольный отказ наследника от обязательной доли в наследстве в пользу иных наследников не допускается в отличие от права на отказ иных наследников по закону. Таким образом, можно прийти к выводу о неравенстве положения наследника обязательной доли по сравнению с иными наследниками при принятии наследства.

Кроме того, согласно общим принципам наследования наследник обязательной доли вместе с приобретением прав на имущество также принимает долговые обязательства наследодателя в пределах стоимости перешедшего к нему имущества солидарно с другими наследниками [6].

Однако для наследников обязательной доли данный принцип противоречит логике и цели обязательного наследования иждивенцами и нетрудоспособными, так как введение на законодательном уровне обязательной доли в наследстве предусматривалось в целях защиты и обеспечения социально незащищенной группы лиц, которые материально зависели от наследодателя и содержались за его счет не менее одного года.

В данном случае происходит уравнивание положения нетрудоспособного наследника с обязательной долей, имеющего неравные возможности по здоровью и материальному обеспечению, с остальными трудоспособными наследниками. При этом законодательство не предусматривает порядок освобождения таких лиц от обязанности погасить долги наследодателя за свой счет.

На практике данная категория наследников в силу социальной незащищенности часто не имеет средств для выплаты долгов наследодателя, и потому обязательная доля становится нежеланным обременением для нетрудоспособного наследника. Учитывая, что долги наследодателя погашаются наследником в пределах стоимости доли, зачастую данная ситуация приводит к фактической утере обязательной доли. Потеря наследственного имущества нетрудоспособным лицом выражается в невозможности его содержания (погашения долгов за счет нетрудоспособного) и добровольном исполнении решения суда о выплате долга кредитору.

Таким образом, полагаем целесообразным внести изменения в статьи 1149, 1175 ГК РФ, которыми бы предусматривалось исключение обязательств нетрудоспособного или несовершеннолетнего лица нести солидарную ответственность по долгам наследодателя наравне с иными наследниками. 


\section{ЛИТЕРАТУРА}

1. ражданский кодекс Российской Федерации часть 3 (ГК РФ часть 3)

2. Трудовой Кодекс РФ.

3. Федеральный закон «0 государственном пенсионном обеспечении в Российской Федерации» от 15.12.2001 N166-Ф3.

4. Постановления Пленума Верховного Суда Российской Федерации по делам о наследовании от 29 мая 2012 г. N9.

5. Определение Верховного суда РФ от 05.11.2019 № 5-КГ19-181

6. Никифоров А. В. Разъяснения Верховным Судом РФ вопросов наследования // URL: https://pravo163.ru/razyasnenie-verxovnym-sudom-rossijskoj-federaciivoprosov-nasledovaniya/.

7. Определение Судебной коллегии по гражданским делам Верховного Суда РФ от 12.07.2016 N49-КГ16-10.

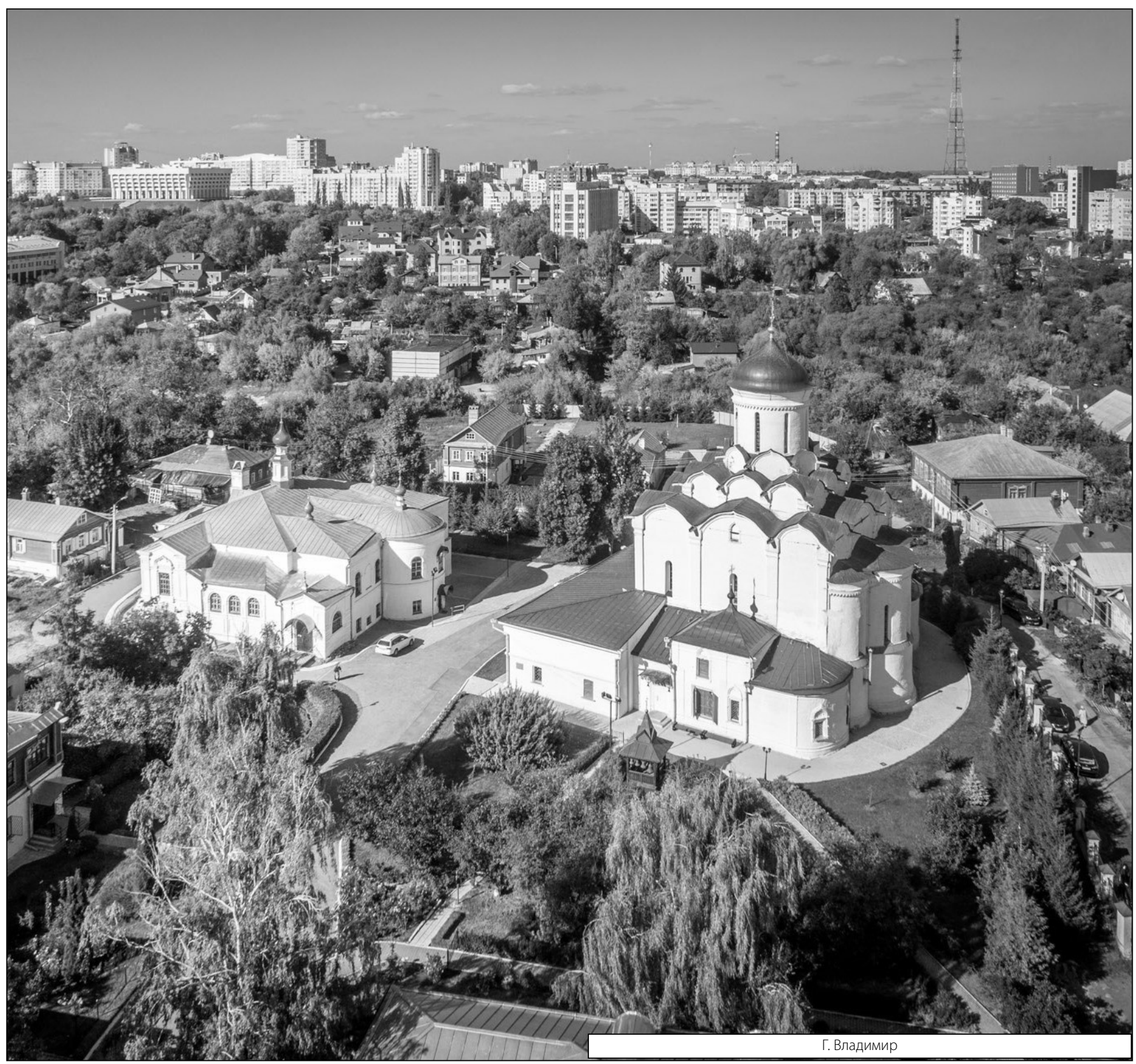

